\title{
Symbolic Meaning of Pakeliran Ki Manteb Soedharsono Entitled Semar Sang Pamomong
}

\author{
Bangkit Irmanudin Bahri \\ Masters Program in Language and Literature Education, Surabaya State University
}

\begin{abstract}
The performance of wayang kulit in commemoration of the $71^{\text {st }}$ anniversary of East Java Province at that time was staged by Ki Manteb Soedharsono with the play Semar Sang Pamomong. This research reveals qualitative and realist ethnography approach to find and analyze the symbolic meaning of Pakeliran Ki Manteb Soedharsono entitled Semar Sang Pamomong. Ki Manteb Soedharsono presented the wayang kulit show entitled Semar Sang Pamomong which contained symbolic aspect of Semar's character as visualization the role of Dr. Soekarwo, S.H., M.Hum. and Drs. Saifullah Yusuf in governing East Java Province, the event of moving Semar was as a spirit to build East Java Province, and content view as a provision of ideology or a view of life to build East Java Province.
\end{abstract}

Keywords: symbolic meaning, character, event, content view

DOI: $10.7176 / J L L L / 59-06$

Publication date: August $31^{\text {st }} 2019$

\section{Introduction}

The performance of wayang kulit in commemoration of the $71^{\text {st }}$ anniversary of East Java Province was staged by Ki Manteb Soedharsono. The determination as dalang considered the quality of Ki Manteb Soedharsono as a famous dalang called dalang setan, sabet dalang who is skilled at moving puppets. Ki Manteb Soedharsono had been in the world of puppetry since childhood. According to Kayam (2001: 203), Ki Manteb Soedharsono was the son of a wayang kulit artist's family, namely his father, a dalang named Ki Hardjo Brahim Hardjowiyono and his mother a singer of gamelan orchestra, (pesinden) and a performer in gamelan orchestra (niyaga). Ki Manteb Soedharsono had been as a student as well as a servant (nyantrik) to famous dalang, including Ki Narto Sabdo and Ki Sudarman Gondodarsono. Groenendael (1987: 42) said, the basis of being a cantrik is admiration for the skills or special knowledge possessed by the master dalang that is expected to be possessed.

Ki Manteb Soedharsono's wayang kulit show became popular in the early 1980s. Ki Manteb Soedharsono's popularity went hand in hand with Ki Anom Suroto and Ki Narto Sabdo. Sears (1996: 260) said, in $1990 \mathrm{Ki}$ Manteb Soedharsono's popularity had exceeded Ki Anom Suroto, because of Ki Manteb Soedharsono's expertise in moving puppets (sabetan) and inserting humor (jokes) in his wayang kulit performances.

Ki Manteb Soedharsono is a person who is persistent, skilled, creative, and innovative, so that he is known by the public as a famous dalang and gets various awards. According to Nurdiyanto and Astuti (2015. 51-59), the achievements that have been achieved by Ki Manteb Soedharsono in the field of puppetry as follows, receiving the Satya Cultural Badge from President Soeharto in 1995, representing the Indonesia dalang received the UNESCO Award in France in 2004, broke the MURI record with a 24-hour 28 minute wayang kulit performance in 2004, receiving the Sang Maestro Award from President Susilo Bambang Yudhoyono in 2009, and receiving the Nikkei Asia Price Award in Japan in 2010.

The communities have the identical name for wayang kulit, namely pakeliran. Satoto (2016: 132) said that it is agreed that the term pakeliran is often used to refer to wayang kulit performances. Pakeliran comes from the basic word kelir, which is the element of wayang kulit performance in the form of a white cloth stretched out with a frame (gawangan). Danardana (1999: 9) said that kelir in the wayang kulit performances was created by Sunan Kalijaga which was arranged together with banana's stem (gedebog), blencong, puppet boxes, and kayon.

Ki Manteb Soedharsono's pakeliran combined the Surakarta and Yogyakarta styles according to what his teacher had done, namely Ki Narto Sabdo in the 1980s. Soetarno (2005: 24) said that the integration of Surakarta and Yogyakarta styles can be observed in the scene gara-gara which use complete Mataraman puppetry style scenes.

Ki Manteb Soedharsono presents a wayang kulit performance with the Semar Sang Pamomong play. The play in the wayang kulit performance can be interpreted as the title of the story. Supratno (2010: 50) said, the play comes from the word "laku" that gets suffix -an. The total presentation of wayang kulit performances combines the play structure and performance structure with the ultimate goal of providing high-value entertainment. Amir (1991: 37-38) said, puppets are the presentation of total quality drama through the unification of the contents of the play and performances that contain serious entertainment involving intellectual, cultural, philosophical, and artistic abilities.

Wayang kulit performances are known as literary and artistic works that are full of meaning and symbols. Herusatoto (2008: 178) said that puppet art is a summary of integrated symbolic actions. Wayang kulit as a work 
of art has a distinctive characteristic that symbolizes symbolic meaning. Haryanto (1992: 29-47) said, symbolism in wayang kulit is reflected in (1) various wanda in Javanese wayang, (2) genetics in the world of puppets, and (3) candra panca as a guide of the puppets characteristics. Wayang kulit performances as a whole contain symbolic meanings contained in each element of their performance. According to Soetarno (2005: 151-201), the symbolic meaning of wayang kulit consists of several parts, including (1) symbolic meanings of puppet show elements, (2) symbolic meanings of puppet shows, and (3) symbolic meanings contained in each wayang kulit play. The symbolic meaning in the Semar Sang Pamomong play consists of symbolism of characterizations, events, and content views.

Research on the symbolic meaning of Pakeliran Ki Manteb Soedharsono in Semar Sang Pamomong play is qualitative. According to Moleong (2005: 6), qualitative research is a form of holistic and descriptive research that places researchers in the real world. This study uses a realist ethnographic approach. Creswell (2014: 129) said, realist ethnography is a research approach that produces objective reports about situations obtained from participants in a particular place and written from the perspective of a third person.

The research application is divided into three continuous stages, namely the pre-field stage, the fieldwork stage, and the data analysis stage. The pre-field stage is the process of finding research objects in accordance with the researchers' interests, namely the wayang kulit show schedule. The field work stage is the location and research focus has been determined with the aim of collecting data. The location of this study is the East Java Governor's Building located on Jalan Pahlawan Number 110 Surabaya where wayang kulit performance entitled Semar Sang Pamomong by Ki Manteb Soedharsono. Data collection techniques used in this study included direct observation, interviews, recording, and taking a note. The data analysis stage was started by the process of analyzing the symbolic meaning of Pakeliran Ki Manteb Soedharsono, the Semar Sang Pamomong play.

\section{Symbolism of the Characterization of Semar Sang Pamomong}

The performance of wayang kulit in the $71^{\text {st }}$ anniversary of the East Java Province chose the Semar Sang Pamomong play. The selection of this play has a connection with the character of Semar who is the main figure. Semar's position in the wayang kulit performance with the Semar Sang Pamomong play as god, guardian or tutor (pamong), and panakawan. Those positions have different nature, but interconnected. The meaning of interconnected is different position but it is united in Semar. The character of Semar in the wayang kulit performance with Semar Sang Pamomong play can be seen in Figure 1.

Semar is a character of wayang kulit created by the ancestors of Javanese society. It is proved from the fact that no Semar figure was found in the Ramayana and Mahabarata books that developed in India. Semar appears in Javanese written wayang stories and also puppetry. Javanese literary works that tell Semar are namely Serat Smaradhahana, Serat Purwacarita, Serat Paramayoga, and Serat Pustaka Raja. The work of puppetry tells Semar through several plays, including Semar Ngejawantah, Semar Boyong, Semar Mbangun Kahyangan, Semar, and Semar Mbabar Jati Dhiri. The personality of Semar in that puppet story symbolically has a relation with the East Java Provincial Government when determining the Semar Sang Pamomong play to commemorate the $71^{\text {st }}$ anniversary of East Java Province.

The performance of wayang kulit entitled Semar Sang Pamomong told about Semar as the incarnation of god. Through Cangik's conversation with Cak Kirun, it could be understood if Semar was Bathara Ismaya's incarnation. Semar went down to the earth with the task of being a virtuous knight guardian. In the story of Ramayana and Mahabarata the position of Bathara Ismaya is juxtaposed with Bathara Wisnu. Hindus have faith that Bathara Wisnu is a god who protects the universe from damage. The duty of guarding and snacking (ngemong) is indeed the responsibility of a pamong which is also held by Semar.

In this wayang kulit performance, Semar Sang Pamomong had duty as a guardian or pamong for virtuous knights, Prabu Rama Wijaya and Pandawa. In fact the story of Ramayana told Semar became pamong of Prabu Rama Wijaya in Pancawati Kingdom, while the Mahabarata story told Semar became pamong of Pandawa in Ngamarta Kingdom. The wayang kulit performance, Semar Sang Pamomong play, told the time of transition from the Ramayana period to the Mahabarata period, so Semar asked Bathara Guru's guidance about the knight who had right to be accompanied by him. Through Bathari Kanastren who was sent to Kayangan Suralaya, Semar got a hint that it was the Kingdom of Pancawati's time to be taken by gods and Pandawa had right to be fostered.

Semar as a pamong who came from a group of proletariat, so it was also called panakawan. The term panakawan comes from the pana word in ancient Javanese language which means to know or understand and kawan means friend, so it can be said that someone who can understand his friend's condition. At this time panakawan is as a term for someone or group that can amuse/entertain the master or bendara. Sometimes there are parties call panakawan in terms of punakawan. The position of panakawan is actually similar to abdi or batur which means servant. The performance of wayang kulit entitled Semar Sang Pamomong told the story of Semar who was always loyal to the Pandawa as his bendara.

Semar is a figure who has three different positions, namely as a god who governs the life of creatures, the 
pamong who nurture virtuous knights, and panakawan who serve bendara. Semar never left his obligations, so Semar was called Bogasampir, Dyah Juru Ispuntaprasanta, and Bojagati. Bogasampir means a god in a human form, also a human of god's incarnation. Dyah Juru Ispuntaprasanta means pamong of virtuous knight. Bojagati means servants who are always obedient to bendara. Based on those different positions, it is worth mentioning that Semar means samar, vague or uncertain and unclear figure.

The Government of East Java Province through the performance of wayang kulit with Semar Sang Pamomong play wanted to convey a message to the people of East Java Province to always support the government and improve the achievements. Selection of the Semar Sang Pamomong play is a form of visualization of the leaders' characters of the East Java Province, Dr. Soekarwo, S.H., M.Hum. and Drs. Saifullah Yusuf, using the character Semar in the puppet story. Some points that linked the character of Dr. Soekarwo, S.H., M.Hum. and Drs. Saifullah Yusuf with Semar characters can be seen in Figure 2.

Semar is a wayang kulit that has three positions, including the gods that govern the life of creatures, the pamong who nurture virtuous knights, and the panakawan who serve the bendara. If it is observed by the parties faced by Semar consists of three elements, namely beings/creature, knight, and bendara, all of which must be treated differently. In the context of this discussion the three elements in the real world can be called the people of East Java Province. The East Java Provincial Government hopes to treat people of East Java Province with three different treatments according to Semar's character. The East Java Provincial Government treats the people of East Java Province with the nature of regulating when enforcing the law over the people, the nature of nurturing when it comes to welfare of the people, and the nature of serving when giving services to the people.

\section{Symbolism of Event of the Semar Sang Pamomong Play}

The Semar Sang Pamomong wayang kulit show presented a transition story for Semar who took care of Prabu Rama Wijaya and then took care of the Pandawa. This transition story was connected with the background of a series of events took place in the Ramayana and Mahabarata stories. Pamong has an important role for knights, because it also determined the knight's success in carrying out his duties. Semar's role as a pamong is told in the wayang kulit performance of Semar Sang Pamomong as shown in Figure 3.

The first part of the wayang kulit performance of Semar Sang Pamomong play told the conditions of several kingdoms that were not attended by the pamong. The kingdom of Pancawati, Ngastina, and Ngamarta were not attended by Semar who was believed to be a figure of the great pamong. When a country is not guided by pamong, damage will appear. The indicators of the damage that occurred were contemptible leaders, miserable people, and many disasters. The following are story of kingdoms that were not attended by Semar.

Circumstances in Ngastina Kingdom indicated there was a contemptible leader. When receiving envoys from the Ngastina Kingdom, Semar gave a statement that the Ngastina Kingdom government did not act fairly. Prabu Duryudana as a king only emphasized the interests of Kurawa which was a royal family. People had the right to get justice from the government in the nation and state life. The government as the ruling leader must not only prioritize the interests of their family and group, because the nature of the government is the leader of all people in the region they lead.

At that time the condition of Pancawati Kingdom was being hit by an epidemic of infectious diseases, riots and disputes. Infectious diseases were a form of disaster, while riots and disputes were a form of people's misery. Prabu Rama Wijaya shared his concern about the occurred situation in the Pancawati Kingdom to Raden Lesmana. According to the god's guidance, the condition of the Pancawati Kingdom could return to normal if it was attended by Semar as the great pamong. The leader can run the government well if he is accompanied by pamong who always advises. Health and people's welfare are the responsibility of the government as a leader.

Taking along the pamong was as an effort to make changes from damage to virtue, (from evil to good). The effort to make changes was reflected in the attitude of admitting mistakes. The wayang kulit show with Semar Sang Pamomong's play symbolized the guilty feeling in the form of sending an envoy to take along Semar, with any conditions it would be fulfilled. Each kingdom had an envoy to take Semar from Pedukuhan Karang Kadhempel, including Raden Lesmana and Raden Anoman as envoys from the Pancawati Kingdom, Adipati Karna, Patih Sengkuni, and Raden Dursasana as envoys from the Ngastina Kingdom, and Raden Antareja, Raden Gatutkaca, and Raden Antasena was messengers from the Ngamarta Kingdom.

Errors confession needs to be based on the self-introspection attitude to be better. The efforts to take along pamong did not run easily, because it had to go through an exam. Semar gave conditions to the envoys who wanted to bring him along by showing him sekar pudhak tunjung biru. Raden Lesmana and Raden Janaka searched sekar pudhak tunjung biru to Kayangan Suralaya to meet Bathara Guru. Sekar pudhak tunjung biru was contested by Raden Lesmana and Raden Janaka, so it was split up into two between the petals and flowers. The two knights finally gave what was obtained to Semar in Pedukuhan Karang Kadhempel. When sekar pudhak tunjung biru was put together by Semar, Bathari Kanastren appeared who brought instructions from Bathara Guru if it was time for Semar to become Pandawa's pamong.

Making changes means that you will not repeat the mistakes that have been made in the past. Someone 
cannot be said to change into goodness if they still make the same mistake. Semar when he arrived at Ngamarta Kingdom gave advice to the Pandawa not to be careless and went on the spree. The knights must be able to reassure the atmosphere and work in accordance with their respective fields. If the works are carried out according to the respective field, then the development will be directed and successful. Nation and state need people who produce real work, not utterances that vilify others.

The East Java Provincial Government through the Semar Sang Pamomong wayang kulit performance had some hopes to be achieved in the following years. In the Andrawina scene, hope of the government and people of East Java was conveyed in order to remain in a state of safety, glory, and kept away from danger. East Java Governor, Dr. Soekarwo, S.H., M.Hum. and Deputy Governor of East Java, Drs. Saifullah Yusuf visualized in the form of Semar character could make the East Java Provincial Government successful righteous. The relationship between the events of Semar Sang Pamomong and East Java Province can be seen in Figure 4.

In the wayang kulit performance Semar Sang Pamomong play told the condition of the Kingdom of Pancawati, Ngastina, and Ngamarta were damaged. A change was made by taking along Semar. Ngamarta Kingdom got better when Semar was successfully carried by the Pandawa. The sequence of events consisting of damage, change, and kindness were the background of the commemoration of the $71^{\text {st }}$ anniversary of East Java Province. The real condition of East Java Province is conducive, but it needs a change to reach better achievements in the following years. Semar's character as a pamong could change the Ngamarta Kingdom to be the basis of the East Java Governor Dr. Soekarwo, S.H., M.Hum. and Deputy Governor of East Java Drs. Saifullah Yusuf to be able to actualize East Java Province which is full of justice and prosperity.

\section{Symbolism of the Contents Views of the Semar Sang Pamomong Play}

Wayang kulit performances included types of literary works in the form of drama. The essence of literature is a work that reflects real life presented with creativity. Wayang kulit performances present an aesthetic form and lofty content. The wayang kulit performance Semar Sang Pamomong play is presented with a Javanese cultural background, so that it has a content view in the form of Javanese people's life view.

\subsection{Manunggaling Kawula Gusti}

Ki Manteb Soedharsono, through the performance of wayang kulit entitled Semar Sang Pamomong used the term manunggaling kawula gusti to describe the relationship between the leader and the society. Prabu Rama Wijaya reflected a gusti and Semar as a kawula. Essentially the term gusti was not only used to refer to Prabu Rama Wijaya, but other royal leaders such as Prabu Puntadewa, Prabu Kresna, Prabu Baladewa, Prabu Duryudana, and other knights. This nation and state life will be peaceful and prosperous if the leaders and the society can work together. The view of life manunggaling kawula gusti is used to describe the relationship between the government and people of East Java Province who are united to realize a common goal.

\subsection{Obah Ngarep Kobet Mburi}

Leader is a figure who can become an inspiration for people. All actions and work of the leaders will be the spotlight for all people. A good leader will make himself to be an example of life that can be emulated by the people he leads. Raden Janaka and Raden Gatutkaca who were accompanied by panakawan tried to find sekar pudhak tunjung biru to Kayangan Suralaya. When Raden Janaka and Raden Gatutkaca with Raden Lesmana and Raden Anoman fought over sekar pudhak tunjung biru, the panakawan also helped to get the sekar pudhak tunjung biru for their bendara. The life-view obah ngarep kobet mburi was reflected by the loyalty of panakawan who helped their bendara's work. In fact, the life-view obah ngarep kobet mburi is used to describe the actions of the East Java Provincial Government that inspiring and became a role model for the people of East Java Province.

\subsection{Sepi ing Pamrih Rame ing Gawe}

Raden Antareja, Raden Gatutkaca, and Raden Antasena were young knights, sons of Raden Werkudara. They had the knight's personality and are fully responsible for carrying out the tasks given by Prabu Puntadewa as the leader of the Ngamarta Kingdom to take along Semar. The efforts made by the knight were called sepi ing pamrih rame ing gawe. Raden Antareja convinced Semar to be ready carried off and Raden Gatutkaca accompanied Raden Janaka to look for sekar pudhak tunjung biru as a condition to bring Semar. This life-view sepi ing pamrih rame ing gawe is used to describe the actions of the East Java Provincial Government who are always creative and get achievements for the welfare of the East Java Province people.

\subsection{Adigang Adigung Adiguna}

The scene reflects the adigang adigung adiguna character at the Semar Sang Pamomong wayang kulit performance, which was when the Adipati Karna was angry at Semar. Prabu Duryudana sent Adipati Karna, Patih Sengkuni, and Raden Dursasana to bring along Semar, but it was rejected by Semar. Adipati Karna was angry after hearing Semar refusal and said that if he could not be carried off in a subtle way, he would be carried 
off in a rude manner. Keeping away of adigang adigung adiguna is reflected from the actions of the East Java Provincial Government that serve the interests of the East Java Province people.

\subsection{Ambeg Adil Paramarta}

Semar as a pamong gave priority to the ambeg adil paramarta on every occasion. Semar's action to mediate a dispute between the envoys from the Kingdom of Pancawati and Ngastina, then the terms for finding sekar pudhak tunjung biru were proposed. The same terms were also given to delegates from the Ngamarta Kingdom, because Semar did not want any disputes arising from acts of favoritism. The view of ambeg adil paramarta is reflected in the actions of the East Java Provincial Government that serve the interests of theEast Java Province people fairly without status discrimination.

\subsection{Sekar Pudhak Tunjung Biru}

If observed the expression sekar pudhak tunjung biru is not only a series of words without meaning, but implies symbolic meaning. The life of sekar pudhak tunjung biru symbolizes people's spirit belong to the people of East Java Province. Sekar pudhak tunjung biru means pandanus flowers and blue lotus. Sekar pudhak tunjung biru lives in puddles full of dirt, but has flowers that are loved by many people. Beautiful flowers on sekar pudhak tunjung biru can not grow by themselves, but because the plants roots are stuck in a puddle of water filled with dirt. The inspiration that can be taken from the life of sekar pudhak tunjung biru is an excellence that cannot be acquired on its own, but requires heavy sacrifice.

\section{Conclusion}

The East Java Provincial Government conveyed a symbolic message to the residents of East Java Province through the performance of wayang kulit in Semar Sang Pamomong play. The East Java Provincial Government wants the public to know that the East Java provincial government is carried out by imitating the characteristics possessed by Semar, namely regulating, nurturing and serving. The East Java Provincial Government treats people of East Java Province with the nature of regulating when enforcing the law over the people, the nature of nurturing when it comes to welfare of the people, and the nature of service when giving services to the people. The tangible evidence of the success of the East Java Provincial Government led by Dr. Soekarwo, S.H., M.Hum. and Drs. Saifullah Yusuf, are receiving the Samkarya Nugraha Para Samya Purna Karya Nugraha award, the best local government implementation report for five consecutive years starting in 2012-2016, and obtaining A score for the performance accountability system of government agencies from the Ministry of Administrative Reform and Bureaucratic Reform Republic of Indonesia.

The wayang kulit performance with the Semar Sang Pamomong play is based on the safe condition of Surabaya city, nevertheless there was an Aksi Bela Alquran demonstration in Jakarta and countries in the Middle East which were in conflict. The East Java Provincial Government conveyed a message symbolically to the people of East Java Province that the momentum of the $71^{\text {st }}$ anniversary was expected to be an encouragement to build East Java Province. Dr. Soekarwo, S.H., M.Hum. and Drs. Saifullah Yusuf efforts to build the Java Province was symbolized by the ruler of the Ngamarta Kingdom who succeeded in bringing along Semar. The hope of the East Java Provincial Government is the secure and prosperous situation of the Ngamarta Kingdom when having pamong can be realized in East Java Province.

The wayang kulit performance of Semar Sang Pamomong play has content in the form of a Javanese people's life view. The view of the contents of the Semar Sang Pamomong play is about the relationship between the leader and the people, the main leadership, and the democracy spirit. The relationship between the leader and the people is symbolized by the expression of manunggaling kawula gusti and obah ngarep kobet mburi. The main leadership is symbolized by the expression sepi ing pamrih rame ing gawe, keeping away from adigangadigung adiguna, and ambeg adil paramarta. The democracy spirit is symbolized by the phrase sekar pudhak tunjung biru. These three content views of the Semar Sang Pamomong play is expected by Dr. Soekarwo, S.H., M.Hum. and Drs. Saifullah Yusuf as a unifier between the government and the people to build East Java Province.

This research shows that Ki Manteb Soedharsono presented wayang kulit performance the Semar Sang Pamomong play which contains symbolism aspects of Semar's characterization as visualization of Dr. Soekarwo, S.H., M.Hum. and Drs. Saifullah Yusuf in governing East Java Province, the event brought Semar as a spirit to build East Java Province, and view content as a provision of ideology or a life view to build East Java Province. Based on the results of this study, it is formulated a conclusion that pakeliran Ki Manteb Soedharsono has the content of symbolic meanings in the form of characterization, events, and content views.

\section{References}

Amir, Hazim. (1997). "Nilai-nilai Etis dalam Wayang”. Jakarta: Pustaka Sinar Harapan.

Creswell, John W. (2015). "Penelitian Kualitatif dan Desain Riset Memilih di Antara Lima Pendekatan". 
Yogyakarta: Pustaka Pelajar.

Danardana, Agus Sri. (1999). "Sastra Miruda". Jakarta: Pusat Pembinaan dan Pengembangan Bahasa Departemen Pendidikan dan Kebudayaan.

Groenendael, Victoria M. Clara Van. (1987). "Dalang di Balik Wayang”. Jakarta: Pustaka Utama Grafiti.

Haryanto, S. (1992). "Bayang-bayang Adiluhung”. Semarang: Dahara Prize.

Herusatoto, Budiono. (2008). "Simbolisme Jawa". Yogyakarta: Penerbit Ombak.

Kayam, Umar. (2001). "Kelir Tanpa Batas". Yogyakarta: Gama Media.

Moleong, Lexy J. (2005). “Metodologi Penelitian Kualitatif”. Bandung: PT Remaja Rosdakarya.

Nurdiyanto dan Sri Retna Astuti. (2015). "Ki Manteb Soedharsono Profil Dalang Inovatif'. Yogyakarta: Balai Pelestarian Nilai Budaya.

Sastroamidjojo, Seno. (1964). "Renungan tentang Pertunjukan Wayang Kulit”. Jakarta: PT Kinta.

Satoto, Soediro. (2016). “Analisis Drama dan Teater 1". Yogyakarta: Penerbit Ombak.

Sears, Laurie J. (1996). "Shadows of Empire Colonial Discourse and Javanese Tales". Durham: Duke University Press.

Soetarno. (2005). "Pertunjukan Wayang dan Makna Simbolisme”. Surakarta: STSI Press.

Supratno, Haris. (2010). "Sosiologi Seni, Wayang Sasak Lakon Dewi Rengganis dalam Konteks Perubahan Masyarakat di Lombok". Surabaya: Universitas Negeri Surabaya Press.

Bangkit Irmanudin Bahri. Born in Ponorogo, East Java Province, Indonesia on April 3, 1991. He pursued undergraduate education in the Javanese Language and Literature Study Program, Languages and Arts Faculty, Surabaya State University which graduated in 2013. The author works as a Javanese language teacher in SMP Negeri 20 Surabaya, East Java Province, Indonesia.

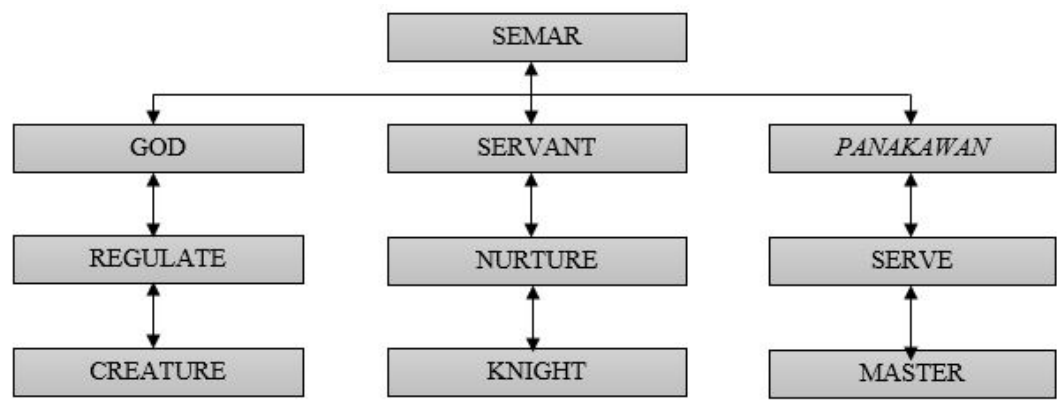

Figure 1: Semar Characterization in Wayang Kulit Semar Sang Pamomong

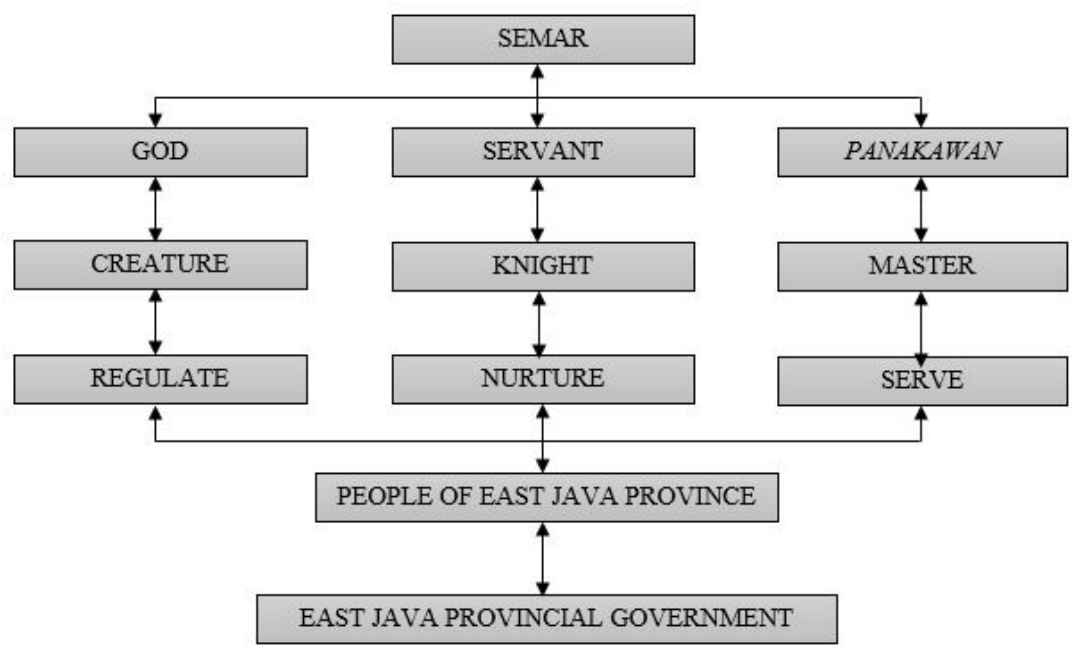

Figure 2: The Relation of Semar characterization and East Java Provincial Government 


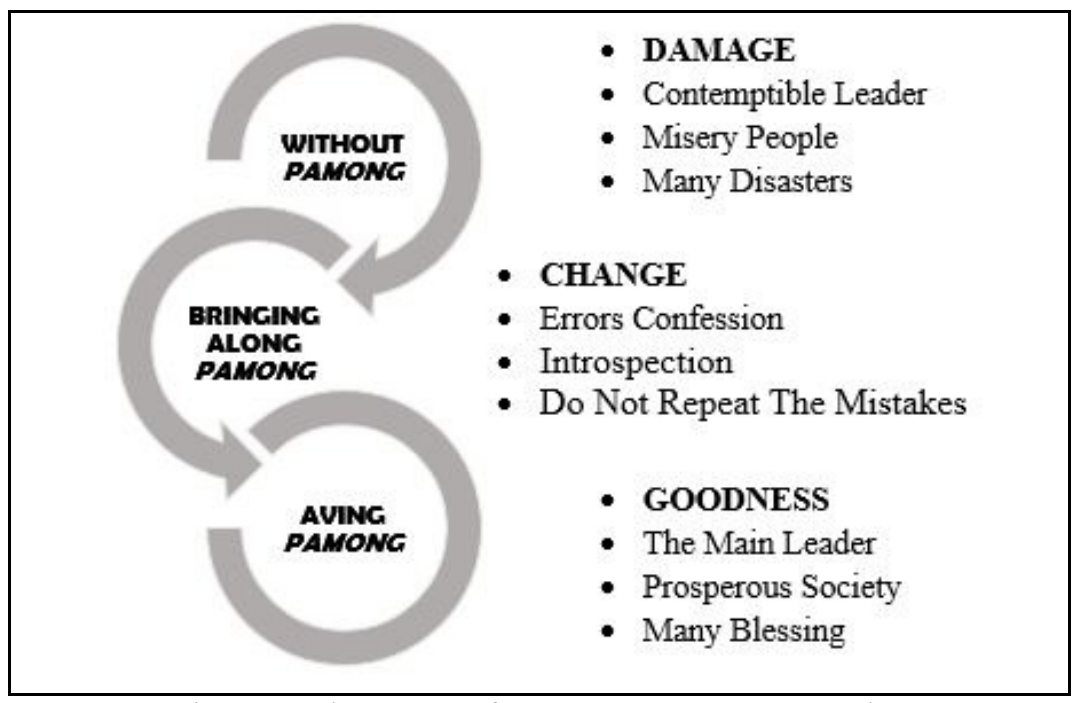

Figure 3: The events of Semar Sang Pamomong play

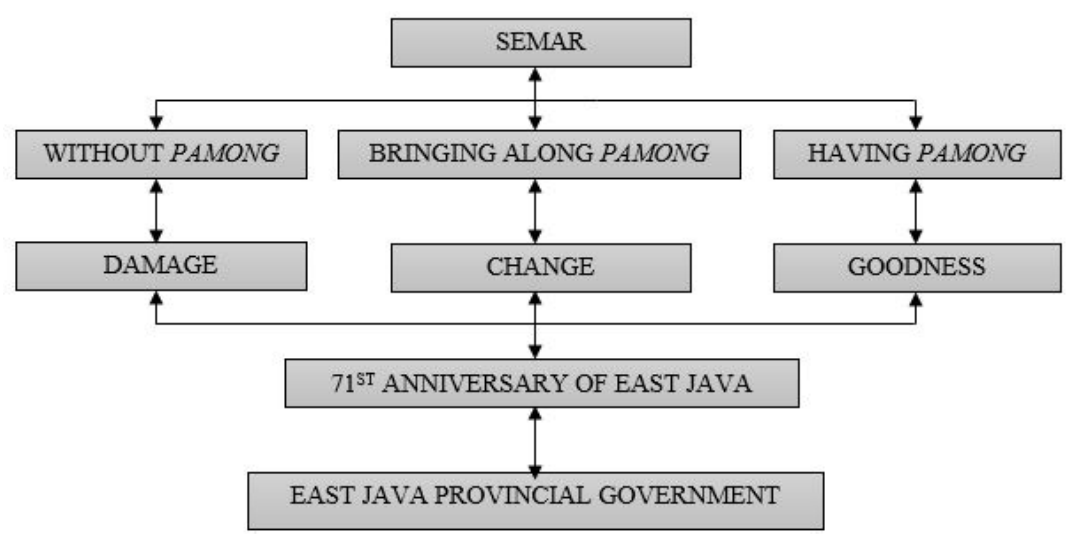

Figure 4: The Relationship between the events of Semar Sang Pamomong play with East Java Province 